\title{
Erratum to: Oxycodone/Naloxone PR: A Review in Severe Refractory Restless Legs Syndrome
}

\author{
James E. Frampton ${ }^{1}$
}

Published online: 21 August 2015

(C) Springer International Publishing Switzerland 2015

\section{Erratum to: CNS Drugs (2015) 29:511-518 \\ DOI 10.1007/s40263-015-0254-y}

The family name of one of the reviewers was incorrect in the original publication. The correct name in the article note should read as S. de Biase.

The online version of the original article can be found under doi:10.1007/s40263-015-0254-y.

James E. Frampton

demail@springer.com

1 Springer, Private Bag 65901, Mairangi Bay 0754, Auckland,

New Zealand 